\title{
Design of Information Teaching in Higher Vocational Education
}

\author{
Wenjun Su \\ Department of Electronic Information \\ Guangzhou Civil Aviation College \\ 10\# Xiangyunxi Street, Guangzhou, Guangdong, China \\ suwenjun@139.com
}

\author{
Haitao Chen \\ Department of Electronic Information \\ Guangzhou Civil Aviation College \\ 10\# Xiangyunxi Street, Guangzhou, Guangdong, China \\ chenhaitao@caac.net
}

\begin{abstract}
The teaching design is based on the task of "optical transmission service interrupt fault processing" in the course of "optical transmission line and equipment maintenance", to discuss Design of information teaching in Higher Vocational Education. Teaching strategies for students to explore, interactive guidance teaching method, learning content with realistic task of multidisciplinary extension module, collaborative work style, teachers as to help, heterogeneous grouping, and evaluation method based on performance are used in the course.
\end{abstract}

Keywords-Teaching design, Information teaching, Higher vocational education, Role plays

\section{INTRODUCTION}

The teaching design is based on the task of "optical transmission service interrupt fault processing" in the course of "optical transmission line and equipment maintenance", to discuss Design of information teaching in Higher Vocational Education.

The course of "optical transmission line and equipment maintenance" is to take employment as the guidance, take the professional ability training as the key point. This course is based on the knowledge, ability and professional quality of the actual job of the job.

This course is organized, arranged and implemented in accordance with the "teaching and learning", "the combination of theory and practice", " the unity of the learning process and the working process" and "the classroom and the training room".

\section{ANALYSIS ON THE CORE PROBLEM OF INFORMATION TEACHING}

\section{A. Analysis of teaching objectives}

This task is based on the requirements of the actual work tasks, to determine the teaching objectives, and to simulate the actual work of the construction of the meaning of the scene around the teaching objectives. In addition to the theoretical knowledge and professional skills, the content of the study also includes the professional quality and safety operation rules.

\section{B. Analysis of the students}

1) Analysis of the starting level

Before studying this subject, students have mastered the optical transmission equipment based on configuration and maintenance skills, and have learned the related theoretical knowledge, and mastered the operation of the device. Students are familiar with network teaching platform in the classroom and network equipment.

\section{2) Analysis of the learning motivation}

Students look forward to achieve their personal value in society, and Teachers need to introduce or provide relevant platform. Students look forward to apply the knowledge in practical work and verify their ability.

\section{3) Analysis of attitude and learning style}

Some students have leadership coordination ability and good communication skills, and active in the work. Some students can work hard. Some students have poor ability and learn passively. In the group work, tasks should be assigned according to the different types and ability of students.

\section{Learning situation design}

Constructivism believes that learning in the actual situation, and it is easier to acquire new knowledge.

The content is from the task of optical transmission line and equipment maintenance of the enterprise, and processed by teaching theory. The relationship between declarative knowledge and procedural knowledge, necessary knowledge and expand knowledge, the theory and practice of knowledge are coordinated.

This teaching processing is to learn the relevant knowledge through the task.

\section{Learning resource design}

In design of information teaching, the students are required to take the initiative to explore the meaning of the knowledge learned to complete the construction based on the abundant resources. The learning resources involved are the following.

(1) A multifunction communication training center.

(2) Teaching video 
(3) The task book

(4) Digital learning resources

(5) Internship resources

(6) Online Q \& A

\section{E. Teaching activity process design}

This study is a combination of individual and group collaboration. Using the combination teaching method of "teaching, learning, doing and testing", the work process characteristics of the "Information - Planning - Decision Implementation - Inspection - Evaluation" six links is reflected in the teaching. according to the content of the curriculum and the characteristics of the students, task driven, case teaching, role play, group discussions, and other action oriented approach to the implementation of a variety of action oriented teaching methods are flexibly used, and students are leaded to think actively and explore.

According to the requirements of the learning task and the results of the study, the students' learning strategies are mainly discussed in this paper, which includes discussion strategy, exploration strategy, cooperation strategy, competition strategy and evaluation strategy.

\section{TEACHING PROCESS DESIGN}

The teaching process of this topic is as follows.

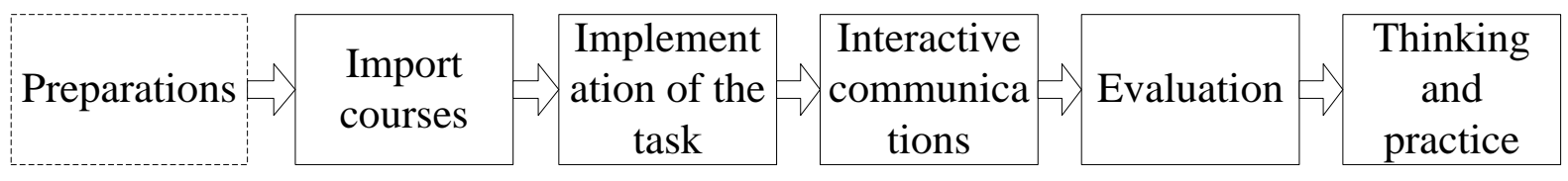

Fig. 1. The teaching process

The teaching methods such as task driving, case teaching, role playing, and group discussion and so on are used.

\section{A. Preparations}

Before studying this topic, we need to tell the following relevant theoretical knowledge in the course. And let the students read through the relevant information through the Internet or library, sum up the common causes and common processing methods of optical transmission interruption failure, and publish them in the course discussion.

\section{B. Import courses}

(1) The theoretical knowledge that this class needs to master will be summarized.

Some students will be selected to show the common causes of the failure of optical transmission and common processing methods using multimedia network teaching platform.

(2) The basic situation and course arrangement will be outlined.

(3) The task will be introduced by playing case video.

\section{Implementation of the task}

1) Teaching purpose

Through the simulation of the interruption in the actual network scenarios, we make the students on the scene and carry on the meaning construction by using case teaching, interactive guidance, group collaboration, role play, summed up the analysis and other means.

\section{2) Teaching content and methods}

(1) The first step: the teacher analyses and demonstrates

The principle of fault location of optical transmission equipment, the common methods of fault location, and the common methods of fault processing of business interruption type are explained. Then the teacher analyses and demonstrates the process of fault treatment.

(2) The second step: group discussion

Using the heterogeneous grouping principle that each group consists of 5 to 6 students, according to the personal ability and characteristics, we do maintenance team role play which include team leader, engineers and troubleshooting librarians.

Team leader organize team members to analyse the causes of failure, discus and arrange work steps.

(3) The third step: students troubleshooting

The teacher transforms fault location, and students perform troubleshooting tasks in group. And students fill in the work page and summary page.

(4)The fourth step: students' exploratory learning

Students which are smart design fault case and exchange case to perform trouble shooting.

\section{Interactive communications}

\section{1) Teaching purpose}

Interactive communication is used to solve the problem which is expected to target. Interaction between teachers and students and the interaction between students are performed on the basis of interactive communications. In the process of interaction, teachers and students can exceed the expected target, and new problems are produced, so that problems can be understood more deeply and comprehensively. Students are enabled to master autonomy, inquiry, interaction and cooperation ability, and students can learn autonomously, and the classroom is changed for interactive park.

\section{2) Teaching content and methods}

(1) The first step: Teacher puts forward the theme and problems of interaction. 
(2) The second steps: group discussion. The group leader organizes the team members to discuss the interactive content, and summarizes everyone's point of view.

(3) The third step: representatives are selected to interact between groups.

\section{E. Evaluation}

Through the teacher evaluation and group evaluation and student self-evaluation, we evaluate the process and results of the task. And we can analyse students' mastery of the teaching objectives, which include knowledge, occupation skills, occupation accomplishment, industry standards and safety norms.

\section{F. Thinking and Practice after-school}

By putting forward thinking after-school, we let students further grasp the topics, and stimulate students' desire to explore. Through the after-school exercises and homework, so that students more firmly grasp the content of the content.

\section{SUMMARY OF INFORMATION TEACHING}

\section{A. Summary of key elements}

The key elements of teaching are teaching strategies, teaching methods, learning content, work style, teacher's role, grouping method, evaluation method and so on. Teaching strategies for students to explore, interactive guidance teaching method, learning content with realistic task of multidisciplinary extension module, collaborative work style, teachers as to help, heterogeneous grouping, and evaluation method based on performance are used in the course.

\section{B. Effect}

TABLE I. EFFECT.

\begin{tabular}{|l|l|}
\hline Information teaching means & Effect \\
\hline Analysis of teaching objectives & To adapt to the requirements of the job position. \\
\hline Analysis of students & To accurately design teaching contents and process, and teach students in accordance with their characteristic. \\
\hline Learning situation design & $\begin{array}{l}\text { Using realistic task for teaching, students are more interested in learning, more active, master what's need in } \\
\text { work. }\end{array}$ \\
\hline Learning resource design & $\begin{array}{l}\text { To make teaching more vivid, learning more convenient, and meet the needs of students' Autonomous } \\
\text { Learning }\end{array}$ \\
\hline Group collaboration, role play & $\begin{array}{l}\text { To cultivate students' sense of teamwork and communication skills, and play each student's different strengths, } \\
\text { and learn from each other. }\end{array}$ \\
\hline Interactive communication & To develop students' ability to summarize, share knowledge and experience, and make progress together. \\
\hline Exploration thinking & To give students more space who is smart. \\
\hline Assessment and competition & To understand the target's grasp, stimulate and maintain the students' learning motivation \\
\hline $\begin{array}{l}\text { Thinking and discussion after } \\
\text { class }\end{array}$ & $\begin{array}{l}\text { Allow students to further grasp the contents of the subject, and stimulate students to explore the desire for } \\
\text { knowledge. }\end{array}$ \\
\hline
\end{tabular}

\section{ACKNOWLEDGEMENT}

This research was financially supported by Program of training excellent young teachers of colleges and universities in Guangdong Province (NO. YQ2015170).

\section{REFERENCES}

[1] Tom Browne, Roger Hewitt, Martin Jenkins, Richard Walker.v2008 survey of technology enhanced learning for higher education in UK. . 2008
[2] Zhang Yichun, Jia Xiaoyan, Liu Ping. Innovation of the Connotations and Development Strategy of Instructional. Informationization in Higher Education Institutions. Modern Distance Education Research. 2011(4).

[3] Boud D. Developing student autonomy in learning [M]. London: Kogan Page, 1988

[4] http://baike.baidu.com/link?url=RuA6gYq8ZokiQWZQAv7MzK9_AW DSjyrVrsJjr8UjPwSj425l3P268oDZOQ5sHd4f91Fqze1JLChDu1ZCm65GK

[5] http://www.moe.gov.cn/publicfiles/business/htmlfiles/moe/s3342/20120 3/133322.htm 